\title{
Isolation and Sequencing of Actin1, Actin2 and Tubulin1 Genes Involved in Cytoskeleton Formation in Phytophthora cinnamomi
}

\author{
Ivone M Martins ${ }^{1,2}$, M Carmen López ${ }^{3}$, Angél Dominguez ${ }^{3}$ and Altino Choupina ${ }^{1,2 *}$
}

${ }^{1}$ Department of Biology and Biotechnology, Polytechnic Institute of Bragança, Apartado 1172, 5301-854 Bragança, Portugal

${ }^{2}$ Mountain Research Center, Polytechnic Institute of Bragança, Apartado 1172, 5301-854 Bragança, Portugal

${ }^{3}$ Department of Microbiology and Genetics, CIETUS-IBSAL, University of Salamanca / CSIC, Plaza de Drs. Queen s/n, 37007 Salamanca, Spain

\begin{abstract}
Oomycetes from the genus Phytophthora are fungus-like plant pathogens that are devastating for agriculture and natural ecosystems. On the Nordeste Transmontano region (northeast Portugal), the Castanea sativa chestnut culture is extremely important. The biggest productivity and yield break occurs due to the ink disease, caused by Phytophthora cinnamomi which is one of the most widely distributed Phytophthora species, with nearly 1000 host species. The knowledge about molecular mechanisms responsible for pathogenicity is an important tool in order to combat associate diseases of this pathogen. Complete open reading frames (ORFs) of act1, act2 and tub1 genes who participate in cytoskeleton formation in $P$. cinnamomi were achieved by high-efficiency thermal asymmetric interlaced (HE-TAIL) polymerase chain reaction (PCR). act1 gene comprises a 1128 bp ORF, encoding a deduced protein of 375 amino acids (aa) and 41,972 kDa. act2 ORF comprises $1083 \mathrm{bp}$ and encodes a deduced protein of 360 aa and $40,237 \mathrm{kDa}$. tub1 has a total length of $2263 \mathrm{bp}$ and encodes a 453 aa protein with a molecular weight of $49.911 \mathrm{kDa}$. Bioinformatics analyses shows that actin1 is ortholog to the act1 genes of Phytophthora infestans, Phytophthora megasperma and Phytophthora melonis; actin2 is ortholog to the act2 genes of P. infestans, Phytophthora brassicae, P. melonis and Pythium splendens and tubulin1 shows the highest orthology to $P$. infestans and $P$. capsici $\alpha$-tubulin genes.
\end{abstract}

Analysed $3 D$ structure of the three putative proteins revealed a spatial conformation highly similar to those described for orthologous proteins obtained by $\mathrm{X}$-ray diffraction.

Keywords: Actin; Castanea sativa; Cytoskeleton; Ink disease; Phytophthora cinnamomi; Tubulin

\section{Introduction}

Phytophthora cinnamomi is a destructive and widespread soilborne oomycete that infects woody plant hosts [1]. On the Nordeste Transmontano region (northeast Portugal), this pathogen is the responsible by the ink disease affecting Castanea sativa chestnut. The most common symptoms are root necrosis and reduction in root growth, which invariably lead to tree death [2]. Due to their particular physiological characteristics, no efficient treatments against diseases caused by these microorganisms are presently available [3]. In order to develop such treatments appeared essential to dissect the molecular mechanisms of the interaction between Phytophthora species and host plants.

Actin and tubulin are highly abundant conserved proteins in eukaryotic cells, which participate in more protein-protein interactions than any other proteins $[4,5]$. These properties, together with the actin capacity to carry out the transition between monomeric (G-actin) and filamentous (F-actin) states under the control of nucleotide hydrolysis, ions, and a large number of actin-binding proteins, make actin a critical player in many cellular functions, ranging from cell motility and the maintenance of cell shape and polarity to the regulation of transcription $[6,7]$. In vertebrates there are three groups of actin isoforms: alpha, beta and gamma. The alpha actins are found in muscle tissues and are a major constituent of the contractile apparatus. The beta and gamma actins co-exist in most cell types as components of the cytoskeleton and act as mediators of internal cell motility. In plants there are many isoforms which are probably involved in a variety of functions such as cytoplasmic streaming, cell shape determination, tip growth, graviperception, cell wall deposition, etc.
A moderate-sized protein consisting of approximately 375 residues, actin is encoded by a large, highly conserved, gene family. Some singlecelled eukaryotes like yeasts and amoebae have a single actin gene, whereas many multicellular organisms contain multiple actin genes. Actin in Phytophthora infestans is encoded by at least two genes, act A and $a c t B$, in contrast to unicellular and filamentous fungi Saccharomyces cerevisiae, Kluyveromyces lactis and Yarrowia lipolytica, where a single gene have been detected $[8,9]$. On the other hand microtubules are major constituents of the cell cytoskeleton participating in a wide range of cellular functions, such as motility, division, maintenance of cell shape, and intracellular transport. Also play an essential role in nuclear division as components of the mitotic spindle and dimeric tubulin is their primary component. A key property of tubulin is its ability to assemble into microtubules via interaction between polymerized $\alpha$ and $\beta$-tubulin monomers (heterodimer), and to undergo disassembly at appropriate times in the cell cycle. However, microtubule role is variable depending on the organism, cell type and other factors.

*Corresponding author: Altino Choupina, Department of Biology and Biotechnology, Polytechnic Institute of Bragança, Apartado 1172, 5301-854 Bragança, Portugal, Tel: +351 273303371; Fax: +351 273325405; E-mail: albracho@ipb.pt

Received July 19, 2013; Accepted August 21, 2013; Published August 28, 2013

Citation: Martins IM, López MC, Dominguez A, Choupina A (2013) Isolation and Sequencing of Actin1, Actin2 and Tubulin1 Genes Involved in Cytoskeleton Formation in Phytophthora cinnamomi. J Plant Pathol Microb 4: 194 doi:10.4172/2157-7471.1000194

Copyright: (c) 2013 Martins IM, et al. This is an open-access article distributed under the terms of the Creative Commons Attribution License, which permits unrestricted use, distribution, and reproduction in any medium, provided the original author and source are credited. 
Citation: Martins IM, López MC, Dominguez A, Choupina A (2013) Isolation and Sequencing of Actin1, Actin2 and Tubulin1 Genes Involved in Cytoskeleton Formation in Phytophthora cinnamomi. J Plant Pathol Microb 4: 194 doi:10.4172/2157-7471.1000194

Page 2 of 5

The aim of this study was to isolate and sequence three genes involved in cytosqueleton formation in P. cinnamomi.

\section{Materials and Methods}

\section{Biological material}

P. cinnamomi isolate Pr120 was isolated from soil samples from sites of $C$. sativa affected by the ink disease on the Nordeste Transmontano region (northeast Portugal). The strain was grown in the dark for 4-6 days at $22-25^{\circ} \mathrm{C}$ in PDA (Potato-Dextrose Agar) medium. This isolate is preserved at the Laboratory of Molecular Biology of the Polytechnic Institute of Bragança (IPB).

Total genomic DNA from P. cinnamomi mycelium was isolated according to the reported methods $[10,11]$.

\section{Fluorescence microscopy}

For nuclei staining, P. cinnamomi mycelium was grown in PDA medium and resuspended in PBS 10X containing $1 \mathrm{mg} / \mathrm{ml}$ of Dapi (4-6-Diamidino-2-phenylindole) (Sigma-Aldrich), and visualized with the appropriate UV filter. For cell wall staining, P. cinnamomi mycelium was grown in PDA medium and resuspended in PBS 10X containing $10 \mathrm{mg} / \mathrm{ml}$ of Calcofluor white (Sigma-Aldrich), using the appropriate UV filter. For actin visualization, $P$. cinnamomi mycelium was grown in PDA medium and stained with $0.1 \mu \mathrm{g} / \mathrm{ml}$ rhodamine-conjugated phalloidin (Invitrogen) [12]. Images were obtained using a Leica HC (Germany) fluorescence microscope, type 020-523.010.

\section{Amplification of the actin and tubulin genes}

PCR was used to amplify act1, act2 and $t u b 1$ genes from $P$. cinnamomi. Degenerated primers Act1 (5'- GYMATGGASGACGAYATTCARGC-3') and Act2 (5'-GYMGYCTTAGAAGCACTTGCGRTG) to amplify act1, Act3 (5'-CAWTCAAGATGGCTGACGAWGAYG) and Act4 (5'-CARCTTAGAAGCACT TGCGGTGC) to amplify act2, were designed based on actin A and B sequences alignment from $P$. infestans. Degenerated primers Tub1 (5'-GGYAATGCSTGTTGGGAAYTMTAT) and Tub2 (5'-CATMCCYTCWCCSAC RTACCAGTG) to amplify tub1, were designed based on a-tubulin sequences alignment from $S$. cerevisiae and $P$. palmivora. The thermal program used for PCR reactions consisted of one cycle of $94^{\circ} \mathrm{C}$ for 5 min, 30 cycles of $94^{\circ} \mathrm{C}$ for $30 \mathrm{sec} ; 57^{\circ} \mathrm{C}$ for $30 \mathrm{sec} ; 72^{\circ} \mathrm{C}$ for $1.5 \mathrm{~min}$ and 1 cycle of $72^{\circ} \mathrm{C}$ for $7 \mathrm{~min}$. Each $25 \mu \mathrm{l}$ PCR contained $0.8 \mathrm{mM}$ dNTPs, 0.2 $\mathrm{mM}$ of each primer, $100 \mathrm{ng}$ genomic DNA, and $2.5 \mathrm{U}$ Taq DNA polymerase in the appropriate buffer. Aliquots of the PCR reactions were separated on $0.8 \% \mathrm{w} / \mathrm{v}$ agarose gels and stained with ethidium bromide, to check for the presence of the expected amplicon. PCR fragments were purified with "DNA and Gel Band Purification" kit (GE Healthcare), following the manufacturer's instructions. Amplified DNA was cloned into pGEM-T Easy (Promega) which is a linearized high-copynumber vector with a single 3 '-terminal thymidine at both ends.

\section{Bacterial transformation and DNA extraction}

Plasmids were propagated in Escherichia coli (DH5a cells, [13]) and plasmid DNA was extracted-purified with the Wizard ${ }^{\circledR}$ Plus SV Minipreps DNA Purification System (Promega), following the manufacturer's instructions. Both DNA fragments obtained were sequenced in a capillar automatic sequencer 3100 Genetic Analyzer (Applied Biosystem).

\section{Amplify unknown genomic DNA sequence of act1, act2 and tubl genes}

HE-TAIL PCR is an efficient method to amplify unknown genomic DNA sequences adjacent to short known regions by flanking the known sequence with asymmetric PCR. In this procedure gene specific primers, Act1.1 (5'-GCCGTTYTCCTTGATCAGCGG), Act1.2 (5'-AGGCGTTGTCGCCCCAGACC), Act2.1 (5'-CGGCCGCGGTGACGCTGACG) and Act2.2 (5'-GGTCTGGGGCGACAACGCCT) were used to amplify unknown genomic DNA sequences of act1 and act2 genes. Gene specific primers Tub1.1 (5'-GCGTTGAACACCAGGAAACCCTG) and Tub1.2 (5'-CGAGATCACCAACAGCGCCTTCGA) were used to amplify unknown genomic DNA sequence of tub1 gene. Degenerated primers R1 (5'-NGTCGASWGANAWGAA), R2 (5'-GTNCGASWCANAWGTT), R3 (5'-WGTGNAGWANCANAGA) and R4 (5'-NCAGCT WSCTNTSCTT) were applied [14]. Three rounds of PCR were performed using the product of the previous PCR as a template for the next (Table 1).

The primary PCR was performed in a $50 \mu \mathrm{l}$ volume containing $80 \mathrm{ng}$ of genomic DNA, $0.2 \mathrm{mM}$ of primers M1 or M3 $2 \mathrm{mM}$ of a random primer (R1, R2, R3, R4), $0.2 \mathrm{mM}$ of each dNTP and $1 \mathrm{U}$ Taq DNA polymerase in the appropriate buffer. The secondary PCR was performed with primers M2 or $\mathrm{S} 4(0.2 \mathrm{mM})$ and the same random primer $\mathrm{R}(2 \mathrm{mM})$ as used in the primary reaction. $1 \mu \mathrm{l}$ of $1 / 50$ dilution of the primary PCR was used as a template. Single-step annealingextension PCR consisting of a combined annealing and extension step at $65^{\circ} \mathrm{C}$ or $68^{\circ} \mathrm{C}$ was used in primary and secondary PCR reactions. The tertiary reaction was carried out with $1 \mu \mathrm{l}$ of $1 / 10$ dilution of the secondary reaction, $0.2 \mathrm{mM}$ of primers $\mathrm{S} 1$ and $\mathrm{S} 2,0.2 \mathrm{mM}$ of random primer $\mathrm{R}$ (the same as used in the previous cycles), $0.2 \mathrm{mM}$ of each dNTP, 1U DNA Taq polymerase in the appropriate buffer. To exclude nonspecific amplification, a tertiary control reaction R-R was set up without adding gene-specific primers.

\section{Amplification of promoter and terminator sequences of act1, act 2 and $t u b 1$ genes}

In this procedure gene-specific primers were designed and, in combination with those, the degenerated primer R2 was applied [14]. Three rounds of PCR were performed using the product of the previous PCR as a template for the next. A detailed cycler program is given in Table 1.

\begin{tabular}{|c|c|c|}
\hline Reaction & $\begin{array}{l}\text { Number of } \\
\text { cycles }\end{array}$ & Thermal settings \\
\hline \multirow[t]{7}{*}{ Primary } & 1 & $93^{\circ} \mathrm{C}(1 \mathrm{~min}) ; 95^{\circ} \mathrm{C}(5 \mathrm{~min})$ \\
\hline & 5 & $94^{\circ} \mathrm{C}(30 \mathrm{sec}) ; 62^{\circ} \mathrm{C}(1 \mathrm{~min}) ; 72^{\circ} \mathrm{C}(2 \mathrm{~min} 30 \mathrm{sec})$ \\
\hline & 1 & $\begin{array}{l}94^{\circ} \mathrm{C}(30 \mathrm{sec}) ; 25^{\circ} \mathrm{C} \text { ramping } 72^{\circ} \mathrm{C}(3 \mathrm{~min}) ; 72^{\circ} \mathrm{C} \\
(2 \mathrm{~min} 30 \mathrm{sec})\end{array}$ \\
\hline & \multirow[t]{3}{*}{15} & $94^{\circ} \mathrm{C}(20 \mathrm{sec}) ; 65^{\circ} \mathrm{C}(3 \mathrm{~min} 30 \mathrm{sec})$ \\
\hline & & $94^{\circ} \mathrm{C}(20 \mathrm{sec}) ; 65^{\circ} \mathrm{C}(3 \mathrm{~min} 30 \mathrm{sec})$ \\
\hline & & $94^{\circ} \mathrm{C}(30 \mathrm{sec}) ; 42^{\circ} \mathrm{C}(1 \mathrm{~min}) ; 72^{\circ} \mathrm{C}(2 \mathrm{~min} 30 \mathrm{sec})$ \\
\hline & 1 & $72^{\circ} \mathrm{C}(5 \mathrm{~min}) ; 4^{\circ} \mathrm{C}$ Hold \\
\hline \multirow[t]{4}{*}{ Secondary } & \multirow[t]{3}{*}{12} & $94^{\circ} \mathrm{C}(20 \mathrm{sec}) ; 65^{\circ} \mathrm{C}(3 \mathrm{~min} 30 \mathrm{sec})$ \\
\hline & & $94^{\circ} \mathrm{C}(20 \mathrm{sec}) ; 65^{\circ} \mathrm{C}(3 \mathrm{~min} 30 \mathrm{sec})$ \\
\hline & & $94^{\circ} \mathrm{C}(30 \mathrm{sec}) ; 42^{\circ} \mathrm{C}(1 \mathrm{~min}) ; 72^{\circ} \mathrm{C}(2 \mathrm{~min} 30 \mathrm{sec})$ \\
\hline & 1 & $72^{\circ} \mathrm{C}(5 \mathrm{~min}) ; 4^{\circ} \mathrm{C}$ Hold \\
\hline \multirow[t]{2}{*}{ Tertiary } & 30 & $94^{\circ} \mathrm{C}(30 \mathrm{sec}) ; 42^{\circ} \mathrm{C}(1 \mathrm{~min}) ; 72^{\circ} \mathrm{C}(2 \mathrm{~min} 30 \mathrm{sec})$ \\
\hline & 1 & $72^{\circ} \mathrm{C}(5 \mathrm{~min}) ; 4^{\circ} \mathrm{C}$ Hold \\
\hline
\end{tabular}

Table 1: HE-TAIL PCR cycle settings. Primary, secondary and tertiary nested PCR reactions were performed sequentially. The primary PCR reaction consists of 15 TAIL cycles, while the secondary reaction contains 12 TAIL cycles. 
Citation: Martins IM, López MC, Dominguez A, Choupina A (2013) Isolation and Sequencing of Actin1, Actin2 and Tubulin1 Genes Involved in Cytoskeleton Formation in Phytophthora cinnamomi. J Plant Pathol Microb 4: 194 doi:10.4172/2157-7471.1000194

Page 3 of 5

The primary PCR was performed in a $50 \mu$ l volume containing $80 \mathrm{ng}$ of genomic DNA, $0.1 \mathrm{mM}$ of gene-specific primers, $2 \mathrm{mM}$ of primer R2, $0.2 \mathrm{mM}$ of each dNTP and $1 \mathrm{U}$ Taq DNA polymerase in the appropriate buffer. The secondary PCR was performed with genespecific primers $(0.2 \mathrm{mM})$ and the same primer $\mathrm{R}(2 \mathrm{mM})$ as used in the primary reaction. $1 \mu \mathrm{l}$ of $1 / 50$ dilution of the primary PCR was used as a template. Single-step annealing-extension PCR consisting of a combined annealing and extension step at $65^{\circ} \mathrm{C}$ or $68^{\circ} \mathrm{C}$ was used in primary and secondary PCR reactions. The tertiary reaction was carried out with $1 \mu \mathrm{l}$ of $1 / 10$ dilution of the secondary reaction, 0.2 $\mathrm{mM}$ of gene-specific primers, $0.2 \mathrm{mM}$ of primer $\mathrm{R} 2,0.2 \mathrm{mM}$ of each dNTP, $1 \mathrm{U}$ DNA Taq polymerase in the appropriate buffer. To exclude nonspecific amplification, a tertiary control reaction R2-R2 was set up without adding gene-specific primers.

\section{Protein structure analysis}

The 3D structure of the proteins was achieved by using the PyMOL $1.3 \mathrm{r} 1$ edu program and Swiss Model [15-17].

\section{Results and Discussion}

\section{Microscopy visualization}

In order to visualize the morphology of P. cinnamomi a staining and microscopic observation of three cell structures was performed (Figure 1): nucleus, through DAPI staining (Figure 1A). Each mycelium presents more than one individualized nucleous. Cell wall was observed by staining with calcoflúor white (Figure 1B) who indicated the lack division septa and actin cytoskeleton and according to [1]. Actin citoskeleton was visualized with rhodamin-phalloidin, although actin distribution can be observed throughout all the mycelium, appeared more concentrated at the hyphae extremities and adjacent to the plasma membrane (Figure 1C), according to [7]. In oomycetes actin forms a cap immediately after the apical plasma membrane, whereas in other organisms like P. cinnamomi, the actin appears in small plates in the tips of hyphae [7].

Hypha of P. cinnamomi also shows strong punctate staining in the sub-apical region, and strong staining bands along the walls of the hypha. Some evidences suggest that microfilaments reinforce the hypha tip of oomycetes. Disruption of the F-actin cap and reduction of F-actin at the tips of oomycetes hypha could, along with cell wall softening, increase tip yielding and thus playing a potential role in invasive hypha growth [7].

\section{act 1, act 2 and $t u b 1$ amplification}

Performing a PCR using genomic DNA from P. cinnamomi as template and degenerated primers designed based on actin $\mathrm{A}$ and $\mathrm{B}$ sequences alignment from $P$. infestans, and the $\alpha$-tubulin sequences alignment from $S$. cerevisiae and P. palmivora, we were able to amplify three fragments of about $1200 \mathrm{bp}$.

After sequencing and bioinformatics analysis, we found that our sequences presented identity with several sequences of the database with the characteristic actin and tubulin domains. We named our sequences Actin1, Actin2 and Tubulin1, EMBL database, accession numbers AM412175.1, AM412176.1 and AM412177.1, respectively.

After performing a HE-TAIL PCR, the fragments of interest were selected and sequenced. By using BioAlign and SeqMan programs we were able to align and analyse the sequences. Through this method we could amplify both promoter (+113 bp) and terminator (+640 bp) of the act 1 gene. We were not able to amplify the promoter and terminator of the act 2 gene because the sequences that we isolated and should flank this gene did not align with the original fragment. For the $t u b 1$ gene we could amplify both promoter (+352 bp) and terminator (+549 bp) regions.

A BLAST analysis (blast.ncbi.nlm.nih.gov) of both genes was performed against Phytophthora, Saccharomyces cerevisiae, Kluyveromyces lactis and Aspergillus nidulans. act1 and act2 of $P$. cinnamomi present an identity of $88 \%$. act1 present an identity of $100 \%$ against $P$. infestans, $P$. megasperma and $P$. melonis and act 2 is ortholog to the act2 genes of $P$. infestans, $P$. brassicae, $P$. melonis and Pythium splendens (100\% identity). act 2 present higher identity to the ascomycetous genes $91 \%$, rather than $78 \%$ of act 1 .

tub1 show $100 \%$ identity to P. infestans and P. sojae and 70\% to $Y$. lipolytica, K. lactis and S. cerevisiae.

\section{D Structure of Actin1, Actin2 and Tubulin1}

After obtaining the deduced amino acid sequence of the act1, act2 and $t u b 1$ genes we have determined the $3 \mathrm{D}$ structure of the proteins using the InterProScan program.

act1 (Figure 2A) presents $82.3 \%$ of identity with the $3 \mathrm{D}$ structure of the reference protein 3 ci5A and act 2 (Figure $2 \mathrm{~B}$ ) presents $86.9 \%$ of identity with the 3D structure of the reference protein 3eksA (described in the data bases). tub1 encodes for a $a$-tubulin protein and presents
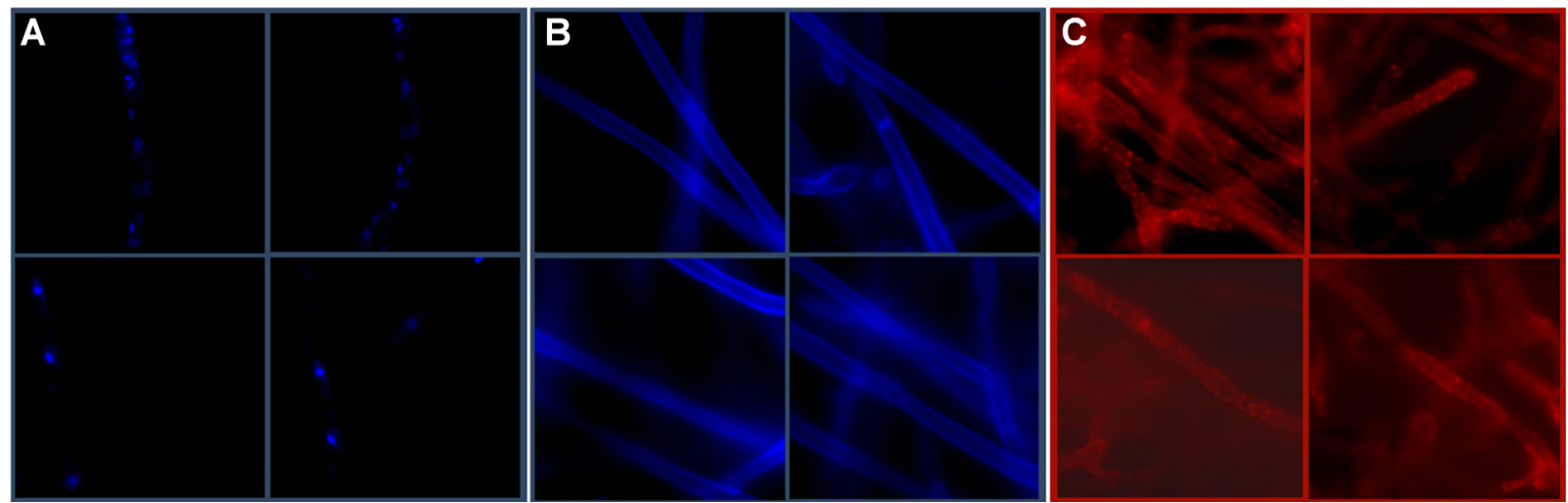

Figure 1: Fluorescence microscopy of stained $P$. cinnamomi mycelium at different locations. A) Each mycelium presents more than one individualized nucleous nuclei when stained with DAPI (1 mg/ml); B) A lack of division septa and actin cytoskeleton is observed in a cell wall stained with Calcofluor white (50 mg/ $\mathrm{ml})$; C) Actin distribution appears more concentrated at the hyphae extremities and adjacent to the plasma membrane when actin cytoskeleton was stained with Rhodamin-Phalloidin $(0.1 \mu \mathrm{g} / \mathrm{ml})$. 

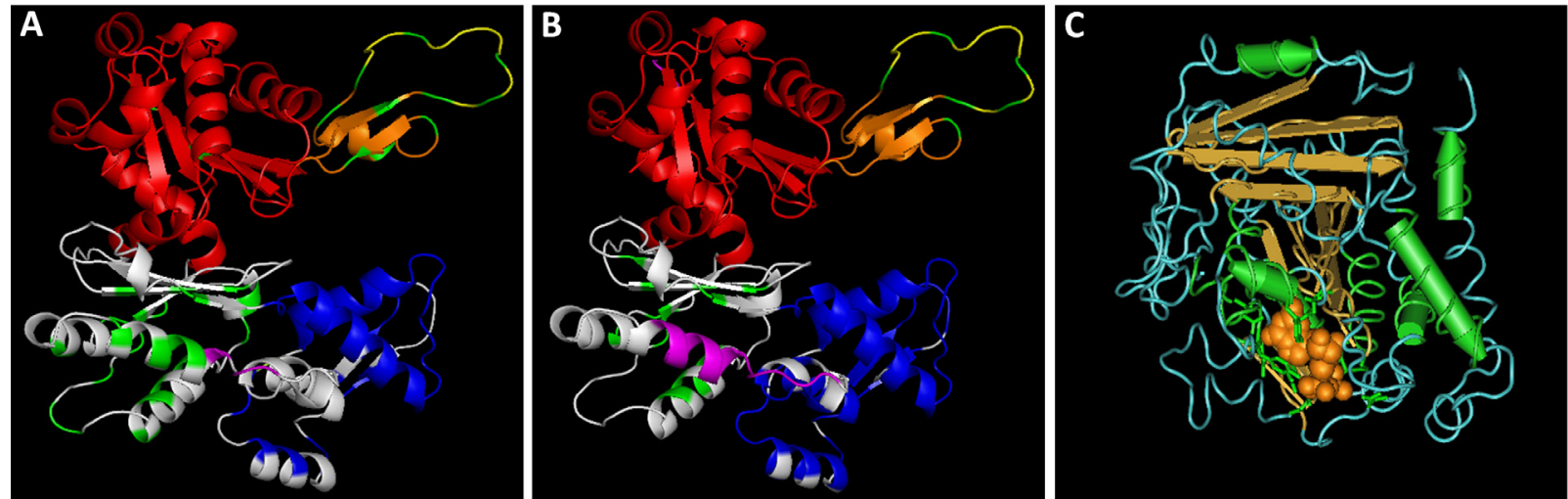

Figure 2: 3D structures of Actin1 Actin2 and Tubulin1. A) 3D structure of the protein encoded by act1, subdomain-1 is represented in red, subdomain-2 in orange, subdomain-3 in white subdomain-4 in blue; B) 3D structure of the protein encoded by act2, subdomain-1 is represented in red, subdomain-2 in orange, subdomain-3 in white subdomain-4 in blue. At subdomain-2 is represented the DNase I chain in yellow (as a loop); C) 3D structure of the protein a-tubulin encoded by the gene tub1, in yellow we can observe the GTP subdomain.

$76.3 \%$ of identity with the $3 \mathrm{D}$ structure of the reference protein $1 \mathrm{Z} 2 \mathrm{~B}$ of the data base. The high identity percentage with the reference protein sequences on the database, allowed us to determine the $3 \mathrm{D}$ structure of the proteins encoded by tub1 (Figure 2C).

Looking at the $3 \mathrm{D}$ structure we can observe the actin proteins subdomains, represented in different colors (Figures 2A and B). Subdomain-1 is represented in red, subdomain-2 in orange, subdomain-3 in white subdomain- 4 in blue. At the subdomain-2 is represented the DNase I chain in yellow (as a loop). Actin from many sources forms a tight complex with deoxyribonuclease (DNase I). The formation of this complex results in the inhibition of DNase I activity, and actin loses its ability to polymerize [18]. Also, subdomain-2 plays an important role in the movement of actin filaments in vivo [19]. In vertebrates, the four $\alpha$-actin isoforms present in various muscle cells and the $\beta$ - and $\gamma$-actin isoforms present in no muscle cells differ at only four or five positions. Although these differences among isoforms seem minor, the isoforms have different functions: $\alpha$-actin is associated with contractile structures, and $\beta$-actin is at the front of the cell where actin filaments polymerize [20]. Actin exists as a monomer in low salt concentrations, but filaments form rapidly as salt concentration rises, with the consequent hydrolysis of ATP. Each actin protomer binds one molecule of ATP and has one high affinity site for either calcium or magnesium ions, as well as several low affinity sites. It has been shown that an ATPase domain of actin shares similarity with ATPase domains of hexokinase and hsp70 proteins.

Regarding the 3D structure of the observe the $\alpha$-tubulin protein, we can observe the $\alpha$-tubulin protein encoded by the gene $t u b 1$ as well as the GTP domain (aa residues D82, T129, V161, S162, E167, N190, Y208). At microtubules the $\alpha$-tubulin subunit contains GTP while the $\beta$-tubulin subunit contains ATP. Microtubules assemble by polymerization of $\alpha-\beta$ dimers of tubulin. Polymerization is a polar process that reflects the polarity of the tubulin dimer, which in turn dictates the polarity of the microtubule [21]. To form microtubules, the dimers of $\alpha$ - and $\beta$-tubulin bind to GTP and assemble onto the (+) ends of microtubules [5]. The energy to drive the microtubule machine comes from GTP hydrolysis. Tubulin is a GTPase whose activity is stimulated by polymerization. A crucial observation is that tubulin polymerizes in the presence of nonhydrolysable GTP to form stable microtubules. Thus, polymerization is driven by the high affinity of the tubulin-GTP dimer for the end of the microtubule [22].
Because of the extremely high diversity and adaptability of the oomycetes lifestyle it is imperative to dissect the multiple roles of the cytoskeleton and is functional interplay in a range of as many as possible species. Over the next few years more and more structural and regulatory components of the oomycete cytoskeleton will be localized and their dynamic interactions that ultimately generate function and determine cell form will be studied in vivo.

\section{Acknowledgments}

This study was supported by the project COMBATINTA/SP2.P11/02 Interreg IIIA-Cross-Border Cooperation Spain-Portugal, financed by The European Regional Development Fund.

\section{References}

1. Erwin DC, Ribeiro OK (1996) Phytophthora diseases worldwide, American Phytopathological Society Press, St. Paul, Minnesota, USA.

2. Abreu CG (1996) Doença da tinta: causas e consequências do declínio do castanhal. Estudos Transmontanos 6: 269-289.

3. Hardham AR (2005) Phytophthora cinnamomi. Mol Plant Pathol 6: 589-604.

4. Dominguez R, Holmes KC (2011) Actin Structure And Function. Annu Rev Biophys 40: 169-186.

5. Heald R, Nogales E (2002) Microtubule dynamics. J Cell Sci 115: 3-4.

6. Kabsch W, Holmes KC (1995) The actin fold. Faseb J 9: 167-174

7. Walker SK, Chitcholtan K, Yu Y, Christenhusz GM, Garrill A (2006) Invasive hyphal growth: an F-actin depleted zone is associated with invasive hyphae of the oomycetes Achlya bisexualis and Phytophthora cinnamomi. Fungal Genet Biol 43: 357-365

8. $\mathrm{Ng} \mathrm{R}$, Abelson J (1980) Isolation and sequence of the gene for actin in Saccharomyces cerevisiae. Proc Natl Acad Sci U S A 77: 3912-3916.

9. Unkles SE, Moon RP, Hawkins AR, Duncan JM, Kinghorn JR (1991) Actin in the oomycetous fungus Phytophthora infestans is the product of several genes. Gene 100: 105-112.

10. Raeder U, Broda P (1985) Rapid preparation of DNA from filamentous fungi Letters in Applied Microbiology 1: 17-20.

11. Specht CA, DiRusso CC, Novotny CP, Ullrich RC (1982)A method for extracting high-molecular-weight deoxyribonucleic acid from fungi. Anal Biochem 119: 158-163.

12. Alfa C, Fantes P, Hyams J, McLeod M, Warbrick E (1993) Experiments with fission yeast: a laboratory course manual. Cold Spring Harbor Laboratory Press, Cold Spring Harbor, New York, USA.

13. Hanahan D (1983) Studies on transformation of Escherichia coli with plasmids J Mol Biol 166: 557-580. 
Citation: Martins IM, López MC, Dominguez A, Choupina A (2013) Isolation and Sequencing of Actin1, Actin2 and Tubulin1 Genes Involved in Cytoskeleton Formation in Phytophthora cinnamomi. J Plant Pathol Microb 4: 194 doi:10.4172/2157-7471.1000194

14. Michiels A, Tucker M, Van Den Ende W, Van Laere A (2003) Chromosomal walking of flanking regions from short known sequences in GC-rich plant genomic DNA. Plant Molecular Biology Reporter 21: 295-302.

15. Arnold K, Bordoli L, Kopp J, Schwede T (2006) The SWISS-MODEL workspace: a web-based environment for protein structure homology modelling. Bioinformatics 22: 195-201.

16. Guex N, Peitsch MC (1997) SWISS-MODEL and the Swiss-PdbViewer: an environment for comparative protein modeling. Electrophoresis 18: 2714-2723.

17. Schwede T, Kopp J, Guex N, Peitsch MC (2003) SWISS-MODEL: An automated protein homology-modeling server. Nucleic Acids Res 31: 3381-3385.
18. Lazarides E, Lindberg $U$ (1974) Actin is the naturally occurring inhibitor of deoxyribonuclease I. Proc Natl Acad Sci U S A 71: 4742-4746.

19. Schwyter DH, Kron SJ, Toyoshima YY, Spudich JA, Reisler E (1990) Subtilisin cleavage of actin inhibits in vitro sliding movement of actin filaments over myosin. J Cell Biol 111: 465-470.

20. Lodish H, Berk A, Zipursky L, Matsudaira P, Baltimore D, et al. (2000) Molecular Cell Biology. (4thedn), WH Freeman and Company, New York, USA

21. Howard J, Hyman AA (2003) Dynamics and mechanics of the microtubule plus end. Nature 422: 753-758.

22. Howard J, Hyman AA (2009) Growth, fluctuation and switching at microtubule plus ends. Nat Rev Mol Cell Biol 10: 569-574. 